УДК 616.36+616.2] - $006.311-053.2-06-08$

DOI 10.11603/24116-4944.2016.2.6829

๑I. М. Бензар

Національний медичний університет ілені О. О. Богомольия

\title{
ВІСЦЕРАЛЬНІ ГЕМАНГІОМИ У ДІТЕЙ: ОСОБЛИВОСТІ КЛІНІЧНИХ ПРОЯВІВ, УСКЛАДНЕННЯ, ЛІКУВАННЯ
}

ВІСЦЕРАЛЬНІ ГЕМАНГІОМИ У ДІТЕЙ: ОСОБЛИВОСТІ КЛІНІЧНИХ ПРОЯВІВ, УСКЛАДНЕННЯ, ЛІКУВАННЯ. ГеМаНГіОМИ дихальних шляхів (ГДШ) і гемангіоми печінки (ГП) можуть мати тяжкі клінічні прояви і супроводжуватися ускладненнями, небезпечними для життя. Метою роботи було визначити клінічні прояви, срактори ризику, ускладнення та можливості лікування гемангіом дихальних шляхів і печінки. У дослідження включено 16 дітей віком від 1 до 12 місяців за період 2011-2015 роки. Гдш діагностовано у 7 пацієнтів, ГП-у 8 дітей. Діагноз ГДШ встановлювали за результатами трахеобронхоскопії, КТ з контрастуванням та МРТ. Для діагностики ГП використовували УзД, КТ з контрастуванням, МРТ. Виділяли три види ГП: вогнищеві, багатовогнищеві та дисруні. 14 пацієнтів отримували пропранолол у дозі 2 мг/кг/добу. В дитини з вогнищевою гемангіомою печінки лікування не проводилося, лише спостереження. ГДШ поєднувалися із сегментарними гемангіомами обличчя у 42,3 \%, усі мультисокальні гемангіоми печінки поєднувалися з численними інсрантильними гемангіомами (ІГ) шкіри. Клінічні прояви ГдШ відзначали у віці від 2 до 5 місяців (у середньому 4,2 місяця). Мультифокальні гемангіоми печінки діагностовано у 62,5 \%, дифузні - у 25,0 \% та вогнищеві-в 12,5\%. Дисрузні гемангіоми печінки клінічно проявлялися відразу після народження ознаками печінкової недостатності та гіпотиреоїдизмом. Лікування ІГ дихальних шляхів розпочинали відразу після встановлення діагнозу, термін початку лікування складав 2,5-4,5 місяця, за винятком однієї дитини, в якої лікування розпочато в 1 рік у зв'язку з пізно встановленим діагнозом. Тривалість лікування складала в середньому 16,1 місяця. У дітей з мультифрокальними ІГ печінки лікування розпочинали у віці 2-5 місяців. У дітей з дифузними гемангіомами печінки пропранолол призначали у 14 і 20 днів. Тривалість лікування гемангіом печінки складала в середньому 10,1 місяця. На фроні лікування пропранололом інволюція пухлини настала у всіх пацієнтів. Ускладнень не було. ІГ дихальних шляхів поєднуються із сегментарними гемангіомами обличчя, мультифрокальні гемангіоми печінки - 3 множинними ІГ шкіри. Дифузні гемангіоми печінки ускладнюються печінковою недостатністю і гіпотиреоїдизмом. Неселективний бета-блокатор пропранолол $є$ ефективним у лікуванні ІГ дихальних шляхів і печінки.

ВИСЦЕРАЛЬНЫЕ ГЕМАНГИОМЫ У ДЕТЕЙ: ОСОБЕННОСТИ КЛИНИЧЕСКИХ ПРОЯВЛЕНИЙ, ОСЛОЖНЕНИЯ, ЛЕЧЕНИЕ. Гемангиомы дыхательных путей (ГДП) и гемангиомы печени (ГП) могут иметь тяжелые клинические проявления и сопровождаться осложнениями, опасными для жизни. Целью работы было определить клинические проявления, фракторы риска, осложнения и возможности лечения гемангиом дыхательных путей и печени. В исследование включено 16 детей в возрасте от 1 до 12 месяцев за период 2011-2015 годы. ГДП диагностировано у 7 пациентов, ГП - у 8 детей. Диагноз ГДП устанавливали по результатам трахеобронхоскопии, КТ с контрастированием и МРТ. Для диагностики ГП использовали УзИ, КТ с контрастированием, МРТ. Выделяли три вида ГП: очаговые, многоочаговые и дифффузые. 14 пациентов получали пропранолол в дозе 2 мг/кг/сутки. У ребенка с очаговой гемангиомой печени лечение не проводилось, только наблюдение. ГдП сочетались с сегментарными гемангиомами лица в 42,3 \%, все мультифокальные гемангиомы печени сочетались с многочисленными инфрантильными гемангиомами (ИГ) кожи. Клинические проявления ГдП отмечали в возрасте от 2 до 5 месяцев (в среднем 4,2 месяца). Мультифрокальные гемангиомы печени диагностировано у 62,5 \%, диффрузные - в 25,0 \% и очаговые - в 12,5 \%. Диффузные гемангиомы печени клинически проявлялись сразу после рождения признаками печеночной недостаточности и гипотиреоидизмом. Лечение ИГ дыхательных путей начинали сразу после установления диагноза, срок начала лечения составлял 2,5-4,5 месяца, за исключением одного ребенка, у которого лечение начато в 1 год в связи с поздно установленным диагнозом. Продолжительность лечения составляла в среднем 16,1 месяца. У детей с мультифокальными ИГ печени лечение начинали в возрасте 2-5 месяцев. У детей с дифрфузными гемангиомами печени пропранолол назначали в 14 и 20 дней. Продолжительность лечения гемангиом печени составляла в среднем 10,1 месяца. На фоне лечения пропранололом инволюция опухоли наступила у всех пациентов. Осложнений не было. ИГ дыхательных путей сочетаются с сегментарными гемангиомами лица, мультисокальные гемангиомы печени - с множественными ИГ кожи. Диффузные гемангиомы печени осложняются печеночной недостаточностью и гипотиреоидизмом. Неселективный бета-блокатор пропранолол является эфрфективным в лечении ИГ дыхательных путей и печени.

VISCERAL HEMANGIOMAS IN CHILDREN: CLINICAL FEATURES, COMPLICATIONS, AND TREATMENT OPTIONS. Airway and hepatic hemangiomas $(\mathrm{HH})$ may have severe clinical manifestations and accompanied by life-threatening complications. The aim of the work was to estimate the clinical signs, risk factors, complications and treatment options of $\mathrm{AH}$ and $\mathrm{HH}$. The study enrolled 16 children aged 1-12 months during 2011-2015. AH was diagnosed in 7, HH - in 8 children. Diagnosis of AH was established by tracheobronchoscopy, CT with contrast, and MRI. For HH diagnostic methods were ultrasound, CT with contrast and MRI. There are three types of $\mathrm{HH}$ : focal, multifocal, and diffuse. 14 patients received propranolol in dose of $2 \mathrm{mg} / \mathrm{kg} /$ day. In patient with focal $\mathrm{HH}$ performed only observation. AH is accompanied by face segmental hemangiomas in $42.3 \%$, all patients with multifocal $\mathrm{HH}$ have multiple skin infantile hemangiomas (IHs). Clinical signs of AH documented in average age 4.2 months (range, 2-5 months). Among HH $62.5 \%$ were focal, $25.0 \%$ multifocal, and $12.5 \%$ diffuse. Diffuse $\mathrm{HH}$ clinically manifested immediately after birth with signs of liver failure and hypothyroidism. Treatment of AH starts immediately after diagnosis, in the age range $2.5-4.5$ months, except one 12 month patient with late diagnosis. Average treatment duration was 16.1 months. In children with multifocal $\mathrm{HH}$ treatment starts in age 2-5 months. In children with diffuse $\mathrm{HH}$ propranolol treatment starts in 14 and 20 days. The duration of treatment of liver hemangiomas is an average of 10.1 months. Treatment with propranolol was effective, involution of the tumor occurred in all patients. We have not any complications. AH is accompanied by segmental face hemangiomas, multifocal $\mathrm{HH}$ are combined with multiple skins IHs. Diffuse HH complicated by liver failure and hypothyroidism. Nonselective beta-blocker propranolol is effective in treating hepatic and airway hemangiomas. 


\section{Педіатрія}

Ключові слова: гемангіома печінки, гемангіома дихальних шляхів, пропранолол.

Ключевые слова: гемангиома печени, гемангиома дыхательных путей, пропранолол.

Key words: hepatic hemangiomas, airway hemangiomas, propranolol.

ВСтУП. Гемангіома - найбільш розповсюджена судинна пухлина дитячого віку, яка уражає від 4 до $10 \%$ малюків першого року життя. Частота гемангіом внутрішніх органів не відома, оскільки вони нерідко перебігають безсимптомно і можуть бути випадково виявлені під час обстеження 3 іншого приводу [1]. Та інколи гемангіоми можуть спричинити тяжкі клінічні прояви і супроводжуватися небезпечними для життя ускладненнями. Найбільш критичними щодо розвитку ускладнень $€$ гемангіоми дихальних шляхів (ГДШ) і гемангіоми печінки (ГП). Ускладненнями ГП можуть бути застійна серцева недостатність, яка поєднується із судинними шунтами всередині печінки, гостра печінкова недостатність, гіпотиреоїдизм, абдомінальний компармент-синдром [2].

Також певні непорозуміння спричинює неоднорідна термінологія, яка зустрічається у різних джерелах. Зокрема, зустрічаються терміни «капілярна», «кавернозна», а термін «ангіома» вживається для характеристики як інфантильних гемангіом, так і судинних мальформацій, які діагностують у будь-якому віці [3]. Для уникнення непорозумінь у термінології ми пропонуємо використання оновленої ISSVA класифрікації 2014 року, прийнятої на генеральній асамблеї Всесвітньої організації з вивчення судинних аномалій [4]. Згідно із запропонованою класифікацією, гемангіоми є доброякісними пухлинами, які поділяються на інфантильні гемангіоми (ІГ) і уроджені. Уроджені, у свою чергу, діляться на гемангіоми зі швидкою інволюцією і без інволюції.

Мета дослідження - визначити клінічні прояви, фрактори ризику, ускладнення та результати лікування гемангіом дихальних шляхів і печінки.

МАТЕРІАЛИ ТА МЕТОДИ. У дослідження включено 16 дітей віком від 1 до 12 місяців, які перебували на стаціонарному лікуванні в Національній спеціалізованій дитячій лікарні «ОХМАТДИТ з за період 2011-2015 роки, в яких виявлено гемангіоми внутрішніх органів. ГДШ діагностовано у 7 пацієнтів. Діагноз ГДШ встановлювали за результатами трахеобронхоскопії, проведеної у дітей з порушенням зовнішнього дихання (стридор, задишка, ціаноз). Для підтвердження діагнозу виконували КТ з контрастуванням $(\mathrm{n}=6)$ та МРТ (n=1). ГП діагностовано у 8 пацієнтів. Скринінговим методом діагностики є ультразвукове дослідження (УЗД), яке проводили в режимі сірої шкали і кольорового доплерівського сканування (КДС). Для об'єктивної візуалізації ГП у 7 пацієнтів було виконано КТ з контрастуванням та в одного - МРТ. На основі аналізу результатів візуалізації гемангіом печінки виділяли їх три види, які запропонували у 2007 році E. R. Christison-Lagay та ін. [5]: вогнищеві (фокальні), багатовогнищеві (мультифокальні) й дифузні. Лабораторні методи дослідження включали загальний аналіз крові з визначенням тромбоцитів, печінкові проби, коагулограму, рівень гормонів щитоподібної залози в крові. Для лікування ІГ у 14 пацієнтів використовували системну терапію неселективним бета-блокатором пропранололом у добовій дозі 2 мг/кг, розділеній на три прийоми. В однієї дитини з вогнищевою ГП лікування не проводилося, лише спостереження.
РЕЗУЛЬТАТИ ДОСЛІДЖЕННЯ ТА ЇХ ОБГОВОРЕННЯ. Серед 65 дітей, які перебували на стаціонарному лікуванні $з$ приводу гемангіом різної локалізації, ураження внутрішніх органів діагностовано у 15 пацієнтів, що склало 23,1 \%. Шкірні ураження діагностовано у 8 (53,3 \%) дітей, у 3 (42,9\%) з ГДШ та в 5 (62,5\%) пацієнтів 3 ГП, причому характер цих уражень відрізнявся. При ІГ дихальних шляхів виявлено сегментарні гемангіоми нижньої частини обличчя, з двобічним ураженням, при ГП мультифокальні гемангіоми печінки поєднувалися з численними (більше 10) ІГ шкіри. Клінічні прояви ГДш відзначали у дітей віком від 2 до 5 місяців (у середньому 4,2 місяця) у вигляді стридора $(n=5)$, «гавкаючого» кашлю, стійкого до антибактеріальної терапії $(n=1)$, ціанозу при годуванні й неспокої дитини $(n=5)$. За результатами КТ та МРТ, в однієї дитини IГ представлена локальним вогнищем у нижній третині трахеї, що звужує просвіт на 80 \%, в інших 6 дітей це дисузне, інколи циркулярне, ураження переважно підзв'язкового простору з поширенням тканини гемангіоми у середостіння і компресією трахеї зі звуженням її просвіту на 60-80 \%. Клінічні прояви ГП визначалися їх видом. Мультифокальні ГП діагностовано у 5 (62,5\%), дифузні - у 2 (25,0 \%) та вогнищеву гемангіому - в однієї дитини (12,5 \%). Усі мультифрокальні ГП супроводжувалися шкірними ураженнями, функція печінки не порушувалась, показаннями до початку лікування були виразкування шкірних ІГ і больовий синдром. Дифузні ГП клінічно проявлялися відразу після народження ознаками печінкової недостатності (підвищення рівня трансаміназ, паренхіматозна жовтяниця, гепатомегалія, коагулопатія внаслідок зниження білковосинтезувальної функції печінки), гіпотиреоїдизмом. Лікування ГДШ розпочинали відразу після встановлення діагнозу, термін початку лікування складав 2,5-4,5 місяця, за винятком однієї дитини, в якої лікування розпочато в 1 рік у зв'язку з пізно встановленим діагнозом. Тривалість лікування складала від 10 до 22 місяців, у середньому 16,1 місяця. Зникнення симптомів відмічалося вже через 5-7 днів від початку лікування. У дітей з мультисрокальними ГП лікування розпочинали у віці 2-5 місяців, у фразу активної проліфрерації ІГ і появи ускладнень - шкірних уражень (виразки, біль). У дітей 3 дифузними ГП пропранолол призначали у 14 і 20 днів, крім того, проводились замісна терапія L-тироксином, посиндромна і симптоматична терапія. Тривалість лікування гемангіом печінки складала 8-14 місяців, у середньому 10,1 місяця. На фроні призначення пропранололу інволюція пухлини настала у всіх пацієнтів, у дітей з дифузними ГП виконували контрольну КТ з контрастуванням, у дітей з мультифокальними ІГ проводили лише контроль УЗД. Ускладнень не було. У дитини з вогнищевою ГП лікування проводилося, оскільки порушень функції не було і відмічалась спонтанна інволюція пухлини.

Гемангіоми внутрішніх органів $€$ потенційно небезпечними пухлинами дитячого віку, якщо вони локалізуються у «критичних» ділянках або супроводжуються ускладненнями, в основному за рахунок великих розмірів. Найчастіше зустрічаються гемангіоми печінки і дихальних шляхів 
[1], описують також гемангіоми шлунково-кишкового тракту [6], проте у нашій практиці симптомних гемангіом такої локалізації не було.

Судинні новоутворення печінки зазвичай діагностують при УзД, проте цей метод можна вважати достатнім лише у пацієнтів з типовими безсимптомними ураженнями, у випадку виникнення ускладнень, за необхідності призначення лікування необхідні додаткові методи візуалізації. Багато авторів віддає перевагу MPT [5, 7], яка $€$ неінвазивною і високоінформативною діагностичною процедурою. КТ з внутрішньовенним контрастуванням для діагностики судинних утворів у паренхіматозних органах не поступається в інформативності МРТ, перевагою КТ у цій віковій групі є можливість проводити обстеження без седації, а недоліком - променеве навантаження. У більшості дітей ми провели КТ з контрастуванням, виходячи зі швидкості проведення процедури, технічного забезпечення, необхідності у транспортуванні дитини.

На основі аналізу результатів візуалізації ГП виділено їх три види: вогнищеві (фокальні), багатовогнищеві (мультифрокальні) та дисрузні [2, 5]. Перебіг захворювання, клінічні прояви й ускладнення відрізняються для кожного з видів. Згідно з літературними даними, патогенез розвитку вогнищевої ГП відрізняється від патогенезу мультифокальної і дифузної ГП. Вогнищева ГП є вісцеральним еквівалентом уродженої гемангіоми шкіри зі швидкою інволюцією (RICH), яка еволюціонує протягом внутрішньоутробного життя і до моменту народження досягає свого повного розвитку, в подальшому в неї немає потенціалу росту [8]. Для фокольних ГП не характерне поєднання зі шкірними гемангіомами. Більшість фокальних гемангіом печінки діагностують як пухлиноподібний утвір у відносно здорових дітей як випадкову знахідку при променевому (частіше ультразвуковому) дослідженні органів черевної порожнини. При КТ виявляють добре відмежовану солітарну сореричну пухлину з інтенсивним накопиченням контрасту по периферії та зниженням його інтенсивності в центрі внаслідок тромбозу, некрозу або крововиливів усередину пухлини. Аналізуючи комплекс характерних ознак, ми вважали можливим обмежитися спостереженням у дитини з уродженою гемангіомою печінки великих розмірів, яка не супроводжувалася порушенням фрункції. В ході динамічного спостереження документовано регрес пухлини протягом 8 місяців.

Мультифокальна та дифузна ГП є істинними інфрантильними гемангіомами, які у своєму розвитку проходять той же цикл, що і більш розповсюджені ІГ шкіри: швидкий ріст протягом перших 12 місяців життя і повільна інволюція протягом 1-5 років $[1,7]$. Оскільки ІГ ніколи не рецидивують протягом життя, мають тенденцію до повної інволюції, лише наявність гемангіоми не є показанням до призначення лікування. Багатовогнищеві ГП на КТ 3 контрастуванням являють собою окремі сореричні утвори, відокремлені один від одного нормальною паренхімою печінки. Для багатовогнищевих ГП характерне поєднання з множинними ІГ шкіри, кількість яких може перевищувати сотні $[1,2]$. Власне ускладнення ІГ шкіри стало показанням до призначення системної терапії бета-блокаторами у нашому дослідженні у всіх п'яти пацієнтів. Перебіг мультифокальних гемангіом печінки не ускладнений.
Характерною особливістю дифузної ГП є відсутність нормальної печінкової тканини в ділянці ураження, яка повністю заміщена тканиною пухлини. Велика площа ураження, недостатність нормальної паренхіми $€$ передумовою значно тяжчого клінічного перебігу, ніж при вогнищевих чи багатовогнищевих гемангіомах печінки [9]. Серцева недостатність розвивається зрідка, оскільки великі артеріовенозні шунти не властиві дифузним ГП. Типовими ознаками є порушення функції печінки з метаболічними та коагуляційними розладами. Усі ІГ прискорюють метаболізм 3-го типу йодотропінової деіодінази (D3) - фрерменту, який конвертує тиреоїдний гормон у його неактивну форму, спричинюючи набутий гіпотиреоїдизм. Випадок тяжкого гіпотиреїдизму в дитини з великою гемангіомою печінки спонукав до визначення D3 в пухлині [10], вторинний гіпотиреоїдний стан розвивається при всіх дисузних гемангіомах печінки [2, 9], що ми спостерігали також у наших двох пацієнтів.

Оскільки ІГ дихальних шляхів, як і ІГ інших локалізацій, властива стадійність росту, клінічні прояви зазвичай 3'являються у період проліферації, тобто у віці від 6 до 12 тижнів, проте симптоми можуть бути також більш ранніми чи пізніми. Основними проявами є кашель, стридор, хриплий крик, ціаноз [11]. Високий ризик ІГ дихальних шляхів існує у дітей із сегментарними гемангіомами обличчя в ділянці нижньої щелепи. Сегментарними називають гемангіоми, конорігурація яких відповідає локалізації ембріонального сегмента, таким гемангіомам властива найбільша частота ускладнень, вони потребують більш тривалого та інтенсивного лікування [12]. ІГ дихальних шляхів супроводжувалися сегментарними гемангіомами нижньої частини обличчя у 42,9 \% пацієнтів у нашому дослідженні.

Для діагностики ГДШ застосовують КТ або МРТ з контрастуванням. Гемангіома інтенсивно накопичує контраст, визначається звуження просвіту дихальних шляхів. У випадку підозри на ГДШ в обов'язковому порядку необхідно виконати ендоскопічне обстеження [13]. Ларинготрахеобронхоскопія виконується під загальною анестезією. Типовим $€$ локалізоване, гладке, податливе новоутворення у підзв'язковому просторі. Гемангіома також може бути дифузною, у вигляді яскраво-червоних плям на стінках трахеї без видимого підвищення слизової оболонки.

ІГ внутрішніх органів $€$ потенційно небезпечними для життя захворюваннями. У минулому для лікування ГП використовували складні інвазивні втручання, такі, як перев'язка печінкової артерії [14], резекція, трансплантація печінки $[15,16]$, для лікування ІГ трахеї - вуглекислий лазер, місцево і системно кортикостероїди, резекцію трахеї [11]. Використання медикаментозних засобів, таких, як кортикостероїди, інтерферон 2альфа, цитостатичних препаратів супроводжувалося тяжкими побічними ефектами, від затримки розвитку дитини до парезів, вторинної мієлоїдної лейкемії [17]. Впровадження у лікувальну практику ІГ бета-блокаторів завдяки щасливому випадку відкрило нові перспективи у лікуванні ІГ не лише поверхневих тканин, але і внутрішніх органів, неселективні бетаблокатори рекомендують як препарати першого ряду для лікування ІГ печінки $[2,18]$, дихальних шляхів $[13,19]$, оскільки метод є простим у використанні, безпечним, не вимагає додаткових ресурсів. У нашому дослідженні застосування пропранололу було ефективним у всіх дітей 
з ІГ дихальних шляхів і печінки, побічної дії препарату не відзначали.

В терапевтичному впливі пропранололу на ІГ виділяють ранній, середній і довготривалий ефект, що пояснюють його впливом на три орармакологічні мішені [20]. Ранній ефект (зникнення клінічних проявів через декілька днів після початку лікування) $€$ наслідком вазоконстрикції на фооні зниження вивільнення оксиду азоту. Ефект середньої тривалості спричинює блокування проангіогенних чинників судинного ендотеліального фрактора росту, фактора росту фрібробластів, металопротеїнази і, як наслідок, припинення росту пухлини. Довготривалий ефект пропранололу характеризується індукцією апоптозу в проліферуючих ендотеліальних клітинах, результатом якого $є$ регрес пухлини. Таким чином, призначення пропранололу повинно бути тривалим, не менше 6 місяців. Передчасне припинення лікування може призвести до подальшого росту гемангіоми, необхідності відновлення лікування. Необхідність у більш тривалому лікуванні ми відмітили у пацієнтів з ІГ дихальних шляхів.

ВИСНОВКИ. ІГ внутрішніх органів властиве поєднання з ІГ шкірних покривів. ІГ дихальних шляхів поєднуються із сегментарними гемангіомами обличчя, мультифокальні гемангіоми печінки - з множинними ІГ шкіри. Дифузні ГП мають найбільш тяжкий перебіг, ускладнюються печінковою недостатністю і гіпотиреоїдизмом. Неселективний бета-блокатор пропранолол є ефективним у лікуванні ІГ дихальних шляхів і печінки. Тривалість лікування ГдШ була більшою, ніж ГП

ПЕРСПЕКТИВИ ПОДАЛЬШИХ ДОСЛІДЖЕНЬ. НООбхідні подальші дослідження щодо вивчення віддалених результатів лікування гемангіом внутрішніх органів, профрілактики ускладнень, а також встановлення оптимального часу початку лікування і визначення тривалості лікування.

\section{СПИСОК ЛІТЕРАТУРИ}

1. Fishman S. J. Treatment of visceral vascular tumors In: Mulliken \& Young's Vascular anomalies Hemangiomas and Malformations / John B. Mulliken, Patricia E. Burrows, Steven J. Fishman. -2nd ed. - Oxford University Press, 2013. - P. 239-258.

2. Lessons from a liver hemangioma registry: subtype classification / A. M. Kulungowskia, A. I. Alomarib, A. Chawlaa [et al.] // J. of Ped. Surg. - 2012. - Vol. 47. - P. 165-170.

3. Meyers R. L. Tumors of the liver in children / R. L. Meyers // Surg. Oncol. - 2007. - Vol. 16. - P. 195-203.

4. Vascular Anomalies Classification: Recommendations From the International Society for the Study of Vascular Anomalies / M. Wassef, F. Blei, D. Adams [et al.] // Pediatrics. - 2015. Vol. 136 (1). - P. e203-e215.

5. Hepatic hemangiomas: subtype classification and development of a clinical practice algorithm and registry $/$ E. R. Christison-Lagay, P. E. Burrows, A. Alomari [et al.] // J. Pediatr. Surg. - 2007. - Vol. 42(1). - P. 62-67.

6. Morris G. A. Intestinal hemangioma presenting as recurrent hematochezia in a 6-week-old male / G. A. Morris, L. Stratchko, M. Sabri // J. of Ped. Surg. case reports. - 2015. Vol. 3. - P. 280-282.

7. Multifocal infantile hepatic hemangiomas -imaging strategy and response to treatment after propranolol and steroids including review of the literature / T. Bosemani, K. B. Puttgen, T. A. Huisman, A. Tekes // Eur. J. Pediatr. - 2012. - No. 171(7). - P.1023-1028.

8. Mulliken J. B. Congenital hemangiomas and infantile hemangioma: missing links / J. B. Mulliken, O. Enjolras // J. Am. Acad. Dermatol. - 2004. - Vol. 50. - P. 875-882.

9. Risk factors for mortality in patients with multifocal and diffuse hepatic hemangiomas / K. L. Rialon, R. Murillo, R. D. Fevurly [et al.] // J. Pediatr. Surg. - 2015. - Vol. 50(5). - P. 837-841.

10. Severe hypothyroidism caused by type 3 iodothyronine deiodinase in infantile hemangiomas / S. A. Huang, H. M. Tu, J. W. Harney [et al.] // N. Engl. J. Med. - 2000. - Vol. 343. - P. 185-189.

11. Bitar M. A. Management of congenital subglottic hemangioma: trends and success over the past 17 years /
M. A. Bitar, R. V. Moukarbel, G. H. Zalzal // Otolaryngol. Head Neck Surg. - 2005. - Vol. 132(2). - P. 226-231.

12. Prospective study of infantile hemangiomas: demographic, prenatal, and perinatal characteristics / A. N. Haggstrom, B. A. Drolet, E. Baselga [et al.] // J. Pediatr. - 2007. - Vol. 150 (3). - P. 291-294.

13. Multicenter Evaluation of the Effectiveness of Systemic Propranolol in the Treatment of Airway Hemangiomas / R. G. Elluru, M. R. Friess, G. T. Richter [et al.] // Otolaryngol. Head Neck Surg. - 2015. - Vol. 153(3). - P. 452-460.

14. Special compression sutures: a new surgical technique to achieve a quick decrease in shunt volume caused by diffuse hemangiomatosis of the liver / A. M. Rokitansky, R. J. Jakl, H. Göpfrich [et al.] // Pediatr. Surg. Int. - 1998. - Vol. 14(1-2). - P. 119-121.

15. Hemodynamic failure as an indication to urgent liver transplantation in infants with giant hepatic hemangiomas or vascular malformations - Report of 4 cases / M. MarkiewiczKijewska, W. Kasprzyk, D. Broniszczak [et al.] // Pediatr. Transplant. - 2009. - Vol. 13(7). - P. 906-912.

16. Spectrum of hepatic hemangiomas: management and outcome / B. Dickie, R. Dasgupta, R. Nair [et al.] // J. Pediatr. Surg. - 2009. - Vol. 44(1). - P. 125-133.

17. Sovinz P. Life-threatening hemangiomatosis of the liver in an infant: multimodal therapy including cyclophosphamide and secondary acute myeloid leukemia / P. Sovinz, C. Urban, K. Hausegger // Pediatr. Blood Cancer. - 2006. - Vol. 47. - P. 972-973.

18. Mhanna A. Hepatic infantile hemangiomas treated with oral propranolol-a case series / A. Mhanna, W. H. Franklin, A. J. Mancini // Pediatr. Dermatol. - 2011. - Vol. 28(1). - P. 39-45.

19. Propranolol in the treatment of upper airway hemangiomas / A. De Moreno, B. H. Matt, G. Montgomery, Y. J. Kim // Ear Nose Throat J. - 2013. - Vol. 92(4-5). - P. 209-214.

20. Storch C. H. Propranolol for infantile haemangiomas: insights into the molecular mechanisms of action / C. H. Storch, P. H. Hoeger // Br. J. Dermatol. -2010. - Vol. 163(2). - P. 269-274.

Отримано 01.08.16 